\title{
Citizen ownership of the state: A measure using election promise implementation score
}

\begin{abstract}
This paper introduces a measure of citizen ownership of the state, which works with empirical data. The paper defines citizen ownership of the state as a condition where whatever the majority of citizens want is implemented. In the present-day large scale state, whatever the majority of citizens want is expressed in the election promises of the winning party, alliance or individuals. The paper argues that the level of implementation of election promises is a measurement of citizen ownership of the state. It models the authority of a representative government to a power of attorney. The citizen as principal awards a power of attorney to the winning party, alliance or individuals as an agent in their election. In the election, the set of election promises of the agent becomes the only written part of the power of attorney. The 2008-2012 tenure of US President Barack Obama is used to test how the methodological approach works with empirical data. The test finds the citizen ownership of the state in the USA at 70.7 percent and the party intrusion into the ownership at 29.3 percent during the tenure.
\end{abstract}

Keywords: Citizen ownership of the state; Representative government; Election promises; Political party; President Obama 


\section{Introduction}

The concept of citizen ownership of the state is related to republicanism and more specifically, democracy. The word republic has originated from the Latin res and publica. Res implies a thing, affairs or interest, and publica means everybody. Thus, the word republic literally means thing or affair that belongs to everybody (LaRosa 2005). Besides, the four basic elements of the state - land, people, government, and sovereignty - are conceptually centered on the existence of citizens. The people themselves are citizens; the land, in general, belongs to citizens; citizens create the government, and, thus, all of these three points mean that the sovereignty of the state is in the hands of citizens.

The constitution of democracies acknowledges citizens as the owner of the state, but political parties in representative democracies apparently challenge this constitutional acknowledgement in practice. The global scenario ranging from Western to non-Western democracies manifests more-or-less uncomfortable relations between citizens and political parties. Especially, nonWestern democracies have witnessed the worst situation in this context as politicians after coming to power usually break their election promises. These democracies also have witnessed partisan approaches and unfair efforts to come and cling to power. A study on Bangladesh shows how political parties exert overwhelming influence on the state machinery and how the so-called democracy has evolved into a 'partyarchy' (BIGD 2015). According to a recent survey, a vast majority of citizens in developing countries thinks that their governments do not listen to them (Pew Research Centre 2014). In Western democracies, Prime Ministers or Presidents have become the dominant political actor (Cameron 2013). Against this backdrop, this paper investigates the question: Do citizens own the state in practice - how can one measure the ownership?

There is no much literature relating to citizen ownership of the state. Karl Marx' revolutionary thoughts found the state belonging to owners of the means of production. These owners are 
capitalists in capitalism and proletarians in socialism. However, the ongoing controversy over his claim entered a wider phase at the end of the last century when the state in Eastern Europe got back from the hands of the Proletariat, the then absolute owner of the means of production, to the people in a capitalist society that included non-owners of the means of production too. Pettit's (2008) Condominium Model provides an insight into citizen ownership of the state as the model's apartment owners of a condominium resemble state owners in general. But there is no literal mention of 'citizen ownership of the state' in Pettit (2008) and the Condominium Model does not deal with the party system which this paper is interested in. The only works found are Bezhanyan (2009) and Cummine (2016) that literally use the concept of citizen ownership of the state. They both define the concept as a traditional legal-institutional framework of democracy. Bezhanyan (2009) operationalizes the concept as a right to fight corruption in government mechanism ${ }^{1}$. Cummine (2016) uses the concept in order to explain who will manage sovereign funds in a country. They did not need to measure citizen ownership of the state. Therefore, devising a measure of citizen ownership of the state is still crucial.

Unlike the dearth of the literature on citizen ownership of the state, the literature relating to how or whether governing political parties, alliances or individuals fulfill their promises made to citizens during elections is abundant (e,g. Bradley 1969; David 1971; Fishel 1985; Krukones 1984; Monie're 1988; Pe'try 2002; Pe'try and Collette 2006; Petry and Collette 2009; Pomper 1968; Pomper and Lederman 1980; Rallings 1987; Ringquist and Dasse 2004; Rose 1984; Royed 1996; Royed and Borelli 1997; Royed and Borelli 1999; Thomson 2001; Thomson et al. 2017). Petry and Collette (2009) review 18 studies of election promise fulfilment in North America and Europe. They find that governing parties, on an average, fulfil 67 percent of their electoral promises. However, none of such works links their findings to any idea like citizen ownership of the state. This paper argues that the level of implementation of election promises is a measurement of citizen ownership of the state.

\footnotetext{
${ }^{1}$ Bezhanyan (2009) is an unpublished work that does not provide clear access to the concept of citizen ownership of the state.
} 
The rest of the paper is divided into a few sections. The Theory section explains what the citizen ownership of the state is in a normative term. Then, the Empirical Study Method section designs how to measure citizen ownership of the state with empirical data. The Test section presents findings of a test of the methodological approach using the 2008-2012 term of US President Barak Obama and his election promises. The Conclusion talks about the implications of the paper.

\section{Theory: What is citizen ownership of the state?}

As per social contract and Marxian theories (Evers, 1977; Hühne, 2012; Ritchie, 1891; Sanderson 1963; Semenov 1975), this paper identifies citizens as traditional inhabitants or settlers of the state and considers that the state by birth belongs to its citizens. Therefore, all the laws and judgments that govern the state affairs, including the citizenship, are meant to have approval from the citizens. This paper also considers that the citizenry is universal and if any practices or theories such as the ones based on force or wealth go against this universality that is a result of a distortion of the originality. In accordance with the originality, the state is meant to be run by its owners, the citizen.

The ancient Greek city-state of Athens is by and large an example of such a system. The then Athenian citizens ${ }^{2}$ generally used to formulate laws, execute the laws, and judge the laws and their execution (Blackwell 2003; Jones 1958; Landauer 2014). Thus, Athenian citizens used to get whatever the majority of them wanted from the state. This paper considers the Athenian regime the ideal model of the citizen ownership of the state. But present-day states are so big in terms of geographical area and population that citizens cannot run the state affairs themselves. Therefore, citizens get the state affairs run by their representatives. However, the representative government is not straightforward. Different groups or influential individuals compete to either

\footnotetext{
${ }^{2}$ Many Athenian inhabitants like women and slaves were not recognized as citizens. However, this paper considers just what Athenian citizens used to practice in terms of what citizens are meant to do as owner of the state.
} 
represent citizens or occupy the citizen ownership of the state. A representative election is a possible solution to this effect, but, still, there is a possibility of no acceptable election or no election at all. Once an election is found acceptable, it is considered that the state has a representative government.

Considering the points made above, this paper primarily defines citizen ownership of the present-day large scale state as a condition where whatever the majority of citizens want from the state is implemented. But, in such a large-scale state, how is it possible to know what the citizens want the state to do? Also, how can one determine what the state does not do, or does something that goes against what the citizens want? Citizens usually choose their representative individuals, party or alliance based on, among others, their current election promises, past promise fulfillment records, overall performances, their general characteristics, ideologies and programs. Among those, election promises are apparently most relevant, specific and welldocumented. In elections, individual candidates, different parties and alliance place their promises before citizens as to what they will do and do not if voted to govern the state affairs. Such promises are usually expressed in different ways, such as speeches in public meetings, debates and election manifestos.

This paper considers parties or alliances the main contenders in an election. Once citizens vote for a party or alliance or an individual, it is understood that the citizens who vote the party or alliance or individual want what the election promises of the party or alliance or individual say implemented. In case of a presidential system, where the chief executive is recruited through a separate election and not accountable to the parliament for his or her workings, it is understood that the majority of the citizens has voted the winning party or alliance or individuals and wanted what the winning party or alliance or individuals promised during their election campaign fulfilled. In a parliamentary system, where the majority party or alliance of an elected parliament appoints the chief executive such as prime minister and he or she along with his or her cabinet colleagues is accountable to the parliament for their workings, it is understood that 
the majority of the citizens has voted the majority party or alliance and wanted what the majority party or alliance promised during their election campaign fulfilled. But election results do not always produce a majority party or alliance straightaway. In such cases, elected smaller parties or individuals by negotiation between themselves create a majority alliance and form a coalition government. In the process of the negotiations, their conflicting election promises, if any, are compromised or become inactive, and some new promises may also be added to the policy preferences of the newly formed governing coalition. Elected party executives and individuals rightfully make such changes because their election acknowledges their leadership quality and they emerge as leaders, though none of their parties or alliances emerges as the majority party. And, the leadership quality of the smaller parties or individuals apparently convinces their respective voters that any changes in the election promises in the process of forming a coalition government are acceptable. Therefore, in a case where no party or alliance had emerged as a majority party to form the government and some minor parties or alliances after the election got united to form a coalition government, it is understood that the coalition partners' conflicting promises, if any, were compromised or disabled at the levels of the coalition partners and their voters as soon as the coalition was formed. Hence, it is understood that the citizens who had voted for those parties or alliances or individuals separately got united and became the majority and wanted what the non-conflicting promises of the minor parties or alliances or individuals had said during the election campaign kept. In a case of absence of formal political parties in a democracy where elected individuals backed by their informal parties have created an alliance to form a government, it is understood that the conflicting election promises of the alliance partners were compromised or disabled as soon as they formed the government and their non-conflicting promises got together. And, accordingly, it is understood that the citizens who had voted for those individuals separately got united, became the majority and wanted what the non-conflicting promises had said fulfilled.

When the majority of citizens vote for a party, alliance or individuals, who eventually form the government, the promises of the elected party, alliance or individuals become the main part of a 
governing contract between the citizen as the owner of the state and the governing party, alliance or individuals as the governing contractor. It is like an unwritten power of attorney where citizens as the principal appoint the winning political party, alliance or individuals an agent to run the state affairs for the next tenure of government and where the set of election promises is considered as the only written part of the power of attorney.

At a personal level, in a general power of attorney, a person as the principal authorizes another person or persons as an agent or attorney to act on the principal's behalf. The principal generally specifies, among others, the purposes, scope and terms for the power of attorney. To this effect, the principal signs a document witnessed by some other persons. The agent must agree on the document and have the capacity to perform. The power of attorney ends once the agent has completed the task or tasks mentioned in the power of attorney document or when the principal withdraws it (Law Institute Victoria n.d.). The agent also can resign at any time (Bird n.d.).

In this paper, the governing party, alliance or individuals as the agent writes the only document (election promises) of the power of attorney before their election and the citizen as principal approve it by electing the party, alliance or individuals to the government. The election promises work as the task list for the agent. Since the governing party, alliance or individuals themselves write the power of attorney document (election promises), there are no doubts about their agreement on the document and their capacity to carry out the tasks. The tenure of the government is the normal timeframe for the power of attorney although the citizen as the principal can withdraw it anytime and the governing party, alliance or individuals as the agent has the right to resign whenever they want.

Once the winning party, alliance or individuals assume the offices of the government, the power of attorney provides them with crucial responsibilities and required rights. Their responsibilities are to govern the state affairs following their election promises while the rights 
aim at having supports required to fulfill the election promises. Those party, alliance or individuals become a popular agent and win the power of attorney often who fulfill their promises with their rights exercised at a level generally acceptable to the principal.

After a tenure has ended, a comparison between what the election promises had said and how much of the promises were implemented, unimplemented or negatively implemented can answer the question of how much citizen ownership of the state has existed and how much the governing party or alliance intruded into the citizen ownership of the state during their tenure. When the winning party, alliance or individuals go by their election promises while running the state affairs, it understood that they as an agent obey the power of attorney. Conversely, if they do not go by their promises or go opposite to the promises, they breach the power of attorney and act like owners of the state. Also, the power of attorney is meant to be withdrawn by the principal if it is evidently observed that the governing party, alliance or individuals do not go by their electoral promises at all. Furthermore, if they do not even hold any election or even if there are some elections, the electoral competition is solely between the candidates who are nominated by the same party, alliance or individuals and, as a result, the regime does not change, no power of attorney is meant to exist there. In such cases, the governing party, alliance or individuals do not bother to have power of attorney - the state runs on a might-isright basis.

Therefore, the power of attorney status could be divided into four categories: (1) implementation of election promises, (2) non-implementation of election promises, (3) negative implementation of election promises, and (4) absence of a power of attorney. The power of attorney status could be expressed as:

Power of attorney status $=$ Election promises implemented + Election promises unimplemented + Election promises negatively implemented + election not held

Now, the citizen ownership of the state could be expressed in the following form: 
Citizen ownership of the state $=$ Power of attorney status $-($ Election promises unimplemented

+ Election promises negatively implemented + election not held)

Here, the amount of implementation of election promises stands for the amount of citizen ownership of the state. On the other hand, the amount of non-implementation and negative implementation of election promises, and election not held represent the amount of intrusion of the governing party, alliance or individuals into the citizen ownership of the state.

\section{Empirical study method: How to measure citizen ownership of the state}

As per the theory above, there is no need to undertake a study to measure citizen ownership of the state in the countries where a power of attorney does not exist. Those countries are generally rated as not free or non-democracy in traditional democracy indices, such as Polity (Marshall, Jaggers and Gurr 2016), Freedom House (n.d.), Przeworski et al. (2000) and Economist Intelligence Unit (Kekic 2007). Therefore, to undertake such a study, it is obvious to choose a country where a power of attorney exists. In fact, a government tenure is the primary unit of a study of citizen ownership of the state. Such tenures must have been created through an election participated by more than one formal political party in general or more than one informal party like the ones in Tuvalu and recognized as democratic or partly democratic by a traditional democracy measure such as Polity (Marshall, Jaggers and Gurr 2016), Freedom House (n.d.), Przeworski et al. (2000) or Economist Intelligence Unit (Kekic 2007).

To carry out such a study, data are needed about: (1) election promises the governing party, alliance or individuals made to citizens during the election, and (2) their implementation, nonimplementation and negative implementation, if any, during the tenure. The promises that fall under any of the following categories and are expressed along with a specific way of implementation are considered for study:

1. Written election manifestos published by parties, alliances or individuals. 
2. The promises made in a national election forum of a party, alliance or an individual candidate.

3. The ones published as election promises in mass media or in a research article.

4. Statements made by coalition partners, saying what changes they have made in their election promises.

This paper following Thomson et al. (2017) considers a firm commitment as a promise, which is pronounced along with specific "action or outcome" (p. 532). In the case of a large unmanageable number of promises, only focused promises are chosen for study. The promises that get published or discussed in generally recognized mass media, Internet-based news portals, social media and research works, including research sites, are considered as focused promises. Data about election promise implementation status are collected from government disclosures, generally recognized research findings, databases, news reports and analyses published online or in a hard copy. Sources of the data about both election promises and their implementation status are well documented.

In case of unavoidable circumstances, under which a government is not able to implement a promise or even they have to carry out a negative implementation of a promise, the likely affected promise or promises do not come under study. Such circumstances may include but not limited to natural calamities like cyclone, earthquake, flooding; international circumstances like an economic recession, war; and changes in public opinion. The impact of such circumstances is explained in well-documented notes as to how the government was not really in a position to implement the particular promise or promises. Besides, if an issue has been resolved through a referendum or any other direct democratic procedure, which dismisses an election promise, such a promise does not come under study.

In the presidential form of government, the winning presidential election promises and the tenure, while in the parliamentary form of government, the winning parliamentary election 
promises and the tenure come under study. In a presidential system, if a presidential effort to fulfill an election promise has been blocked in the legislature, the particular promise is considered fulfilled partly since there were two different sets of winning election promises one was the president's and the other was the legislature's. For the same reason, in a semipresidential system where there is a kind of balance between parliamentary and presidential systems (see Choudhry and Stacey 2013), if a parliamentary effort to fulfill an election promise has been blocked by the head of the state such as President, the implementation status of the election promise is considered implemented partly. In a case, where some minor political parties or elected individuals have formed a coalition government, only their non-conflicting election promises come under study and the conflicting promises are omitted. If the coalition partners before or after forming their government have made any statements saying what changes they have made in their election promises, those changes come under study. In an event of withdrawal of any partner from an alliance government, the partner's election promises are not covered in the study. If a government has not completed its tenure, the tenure does not come under study. However, if a government had not completed its tenure but the same governing party, alliance or individuals have formed a new government and completed the tenure, the election promises of the party, alliance or individuals come under study for the whole tenure.

This paper assumes that there are available resources required for the implementation of the election promises made by political parties, alliances or individual candidates because they are meant to be responsible for and make implementable promises. And, it is reasonable that false promises fall under the non-implementation category.

This paper uses a nine-point scale (see Table 1) to measure implementation, nonimplementation and negative implementation of promises. The implementation status of every promise for a period under study is assessed and quantified using the scale. The scale points range from '4' (full positive implementation) to '- 4' (full negative implementation). In the case 
of 'yes' or 'no' answer to the question about the implementation status of election promises for the whole tenure of the government, 'yes' is assigned '4', 'no' is ' 0 ' while a negative implementation is ' -4 '. In the case of a proportional implementation of an election promise, the researcher uses their judgment in assigning the right values to the implementation status of the promise realizing the modality of different points on the scale. For example, the implementation of an election promise - 'Income tax will not be increased' - is assigned 3 for the whole four-year tenure if one year of the tenure has witnessed an increase in income tax. Another example of an election promise - the construction of a bridge had just started, and there was no more progress during the tenure of the government. In this case, the quantified implementation status of the promise is 1 , the lowest positive point of the scale before zero.

To calculate a government tenure score of citizen ownership of the state, the number of election promises considered for the study is counted first. Then, all the quantified scores of the positive implementation of promises during the tenure of the governing party, alliance or individuals are added, and the result is subtracted from the total negative implementation score of promises, if any. Then, the total positive implementation score is transformed into percentage point (total promise implementation score $\times 100 \div$ total number of promises multiplied by the highest code, 4), which results in the tenure score of citizen ownership of the state. If an election promise has had some sub-points, the number of sub-points is counted first, and then all the scores of the positive implementation of the sub-points are added, and the result is subtracted from the total negative implementation of the sub-points, if any. Then, the total is divided by the number of sub-points. It results in the implementation score of the promise. The amount of intrusion of the governing party or alliance or individuals into citizen ownership of the state is calculated by subtracting citizen ownership from their base ownership value. Citizens' base ownership value is the total intact value of the election promises that is $100 \%$. For example, if a tenure score of the citizen ownership of the state is found $52 \%$, the intrusion of the governing party, alliance or individuals into the citizen ownership of the state is $48 \%(100-52)^{3}$ for the tenure.

\footnotetext{
${ }^{3}$ For further explanation, please refer to the Test section.
} 


\section{Test}

The 2008-2012 tenure of US President Barack Obama is used to test how the methodological approach to the measurement of citizen ownership of the state works with empirical data. Manifesto Project data (Manifesto Project n.d.) are used as the set of original promises, and from among those, the ones that get focused in research works, mass media and social media are considered for the study. If only a part of a promise mentioned in the Manifesto data has gotten focused in research work, mass or social media, that part is considered as an independent unit of promise. The implementation status of the promises is rated based on the information collected from different sources, including Amadeo (2018), Bradner (2014), Condon (2012), Democracy Now (2017), Holdren (2011), Park (2009), Polity Fact (2017), Siniscalco (2010), Soffen (2017), Sullivan (2012), and Washington Post (2018). The implementation statuses are quantified based on the scale shown in Table 1 and the criteria described in the Empirical Study Method section of this paper. According to the criteria, some promises are considered partly implemented (coded 2 or 3 ) because President Obama made efforts to fulfill those promises although the efforts failed in part (coded 3) or fully (coded 2) in the Congress.

Barack Obama as the Democratic Party nominee was elected President to run the government for the 2008-2012 tenure. During the election campaign, Obama made several promises to citizens, from which precisely 105 promises are considered in this study. Among those, the implementation status of 53 promises scores $4 ; 17$ promises score $3 ; 16$ promises score $2 ; 2$ promises score 1 while the rest 17 score 0 . The implementation status of the election promises reveals that President Obama broke some promises he had made to citizens during his 2008 election campaign. It has resulted in a party intrusion into citizen ownership of the state during the tenure. The citizen ownership of the state stood at 70.7 percent, meaning that the 
Democratic Party as the agent intruded 29.3 percent into the citizen ownership of the state (Appendix A (online version)).

A 70.7 percent implementation of election promises is as usual as the existing election promise fulfillment studies reveal. Petry and Collette (2009) find that the electoral promise fulfillment in the US ranged from 60 percent to 80 percent between 1944 and 1999 while the North American and European rate was 67 percent on an average. Also, President Obama himself observed that he kept 60 percent of his 2008 election promises (Mason 2011).

The findings of this paper are crucial in respect of its methodological strength. The methodological approach this paper uses shows some improvements compared to the approaches used by the existing studies of election promises in the US. There are four criteria introduced by Petry and Collette (2009) for election promise fulfillment research. The criteria are (1) operational definitions of an election promise and (2) its implementation, (3) sourcing of the information and (4) open judgment on the level of distance between a promise and its implementation. None of the works on US electoral promise fulfillment reviewed by Petry and Collette (2009) meets all of these criteria (see Petry and Collette 2009 pp. 71-72) except some recent work like Thomson et al. (2017), which is not reviewed by Petry and Collette (2009). Even the recent works (e.g. Thomson et al. 2017) barely meet the fourth criterion. However, this paper meets all of the four criteria (see Empirical Study Method section, Test section and Appendix A (online version) of this paper). To meet the fourth criterion, this paper uses a 9point scale that covers both positive and negative implementation status of promises and, thus, goes for deeper analysis of the distance between a promise and its implementation status. Such a scale with a wider scope for researchers to use their judgment is unusual in the existing studies of US election promise fulfillment.

As this paper measures citizen ownership of the state, it goes some extra miles. First, totality: this paper focuses on the totality of promises expressed by an individual, party or alliance at a 
national level election instead of randomization, choosing a section of promises or focusing on a geographical part of the state. There are many existing studies (e.g. Bradley 1969; Elling 1979; Royed and Borelli 1997; Royed and Borelli 1999), which use only those promises that match their chosen research topic. Thomson et al. (2017) randomize election promises. Second, conflict analysis: it is seemingly uncommon that the existing promise fulfilment studies employ theory to explain the conflict between different promises, such as presidential versus parliamentary election promises and the election time promises of the partners of a coalition government. This paper explains how and when election promises conflict and get together, abolished or omitted (see Theory section). Third, systematic drop-off: it also leaves a space where some promises can be dropped systematically under exceptional circumstances that do not have an impact on the resulting finding. A well documented explanation of such exceptions is made necessary.

\section{Conclusion}

This paper introduces a measure of citizen ownership of the state, which works with empirical data. The paper defines citizen ownership of the state as a condition where whatever the majority of citizens want is implemented. In the present-day large scale state, whatever the majority of citizens want is expressed in the election promises of the winning party, alliance or individuals. This paper argues that the level of implementation of election promises is a measurement of citizen ownership of the state. It models the authority of a representative government to a power of attorney. The citizen as principal awards a power of attorney to the winning party, alliance or individuals as an agent in their election. In the election, the set of election promises of the agent becomes the only written part of the power of attorney. The 2008-2012 tenure of US President Barack Obama is used to test how the methodological approach to the measurement of promise-keeping works with empirical data. The test proves 
the new approach crucially improved compared to existing approaches, and the findings are found interesting.

However, this paper has some methodological limitations. Among those, first, election promises usually do not cover many general government tasks, which the winning party, alliance or individuals have to deal with while running the state affairs. Second, election promises do not cover unforeseen and unpredictable events or issues, which could get more focused on the practical lives of citizens than the election promises do. Third, different election promises may have different degrees of importance in terms of, among others, their influences on the public lives, but the methodology introduced in this paper cannot capture data on different degrees of importance of election promises because of its static and equal quantification. For example, 'creating a Military Families Advisory Board' and 'bringing the Iraq war to a responsible end' are two promises, and both of them score 4 although their importance may not be the same. Fourth, citizens choose their representative individual, party or alliance based not only on election promises, but this paper relies on election promises only. However, though these limitations weaken the methodology to some extent, such limitations are quite common in scientific studies, especially in the social sciences. These limitations may be dealt with by future researchers.

Also, following the theory and methodological approach used in this paper, a future researcher can carry out a study of citizen ownership of the state using a sample of a past tenure or tenures of government of a single country or multiple countries. A multi-tenure single country sample may facilitate a comparison between government tenures in a single country while a crosscountry sample can facilitate a comparison between countries (see Table 2). Based on the tenure score of citizen ownership of the state, tenures can be ranked on an index that could be called State Owner Perception Index (SOPI). The more the tenure score of citizen ownership of the state, the higher the tenure rank will be. If more than one tenure has attained the same score, those tenures are ranked in alphabetic order. 


\section{Reference}

Amadeo, K. (2018). Obama 2008 economic promises and platform: has Obama kept his promises? Retrieved September 15, 2020 from https://www.thebalance.com/obama2008-economic-promises-and-platform-3305774.

Bird, Beverly. (n.d.). Legal beagle. Retrieved August 2, 2020 from https://legalbeagle.com/7409714-resign-power-attorney.html.

Bradley, J. P. (1969). Party platforms \& party performance concerning social Security. Polity 1(3), 337-358.

Bezhanyan, A. (2009). Citizens' ownership over the state and its role in the principal-agent model of corruption. Academia.edu. Retrieved April 11, 2020 from https://www.academia.edu/925124/Citizens_ownership_over_the_state_and_it s_role_in_the_principal-agent_model_of_corruption.

BIGD. 2015. Bangladesh faces democracy deficit. The Daily Star, March 8. Retrieved August 12, 2020 from http://www.thedailystar.net/bangladesh-faces-democracy-deficit-56342.

Blackwell, C. W. (2003). Athenian democracy: a brief overview. Dèmos: 4-10.

Retrieved 15 September 2020 from http://www.stoa.org/projects/demos/article_democracy_overview?page=4

Bradner, E. (2014). Specter of NAFTA haunts Obama. Retrieved August 12, 2020 from http://www.politico.com/story/2014/02/nafta-barack-obama-trade-mexico-103701.

Cameron, M. (2013). Restoring parliamentary supremacy. Retrieved September 12, 2018 from http://blogs.ubc.ca/cameron/.

Choudhry, S., \& Stacey, R. (2013). Semi-presidentialism as a form of government: lessons for Tunisia. International IDEA and The Center for Constitutional Transitions at NYU Law Working Paper No 2.

Condon, S. (2012). Obama's 2008 promises: kept or broken? CBS News, September 
4. Retrieved August 29, 2020 from http://www.cbsnews.com/news/obamas-2008promises-kept-or-broken/.

Cummine, Angela. (2016). Citizens' Wealth: Why (and How) Sovereign Funds Should be Managed by the People for the People. New Haven and London: Yale University Press.

David, P. T. (1971). Party platforms as national plans. Public Administration Review 31(3), $303-315$.

Democracy Now. (2017). Obama signs Lilly Ledbetter Fair Pay Act. Retrieved 15 September 2020 from https://www.democracynow.org/2009/1/30/headlines/.

Elling, R. C. (1979). State party platform and state legislative performance: a comparative analysis. American Journal of Political Science, 23(2), 383-405.

Evers, W. M. (1977). Social contract: a crtique. Journal of liberation studies, 1(3), 185-194.

Fishel, J. (1985). Presidents and promises: fom cpmpaign pledge to presidential performance. Washington: Congressional Quarterly Press.

Freedom House. (n.d.). Methodology. Retrieved August 22, 2020 from https://freedomhouse.org/reports/freedom-world/freedom-world-research-methodology.

Freedom House: Tuvalu. (n.d.). Retrieved 23 August 2020 from https://freedomhouse.org/country/tuvalu/freedom-world/2020.

Holdren, J. P. (2011). America COMPETES Act keeps America's leadership on target. Retrieved August 11, 2020 from https://obamawhitehouse.archives.gov/blog/2011/01/06/america-competes-actkeeps-americas-leadership-target.

Hühne, T. (2012). The state of nature in John Locke, Thomas Hobbes and Jean-Jacques Rousseau. Munich: GRIN Verlag. Retrieved August 21, 2020 from http://www.grin.com/en/e-book/209611/the-state-of-nature-in-john-locke-thomas(2001)hobbes-and-jean-jacques-rousseau.

Jones, A. H. M. (1958). Athenian democracy. New York: Frederick A. Praeger, Inc. Kekic, L. (2007). The Economist Intelligence Unit's index of democracy. Retrieved 
http://www.economist.com/media/pdf/DEMOCRACY_INDEX_2007_v3.pdf.

Krukones, M. G. (1984). Promises and performance: presidential campaigns as

Policy Predictors. Lanham, MD: University Press of America.

Landauer, M. (2014). The idiōtēs and the tyrant: two faces of unaccountability in democratic Athens. Political Theory, 42(2), 139-166.

LaRosa, B. D. (2005). Democracy or republic, which is it? Retrieved August 22,

2020 from http://www.devvy.com/pdf/larosa/larosa_democracy_or_republic.pdf.

Law Institute Victoria. (n.d.). Powers of attorney. Retrieved September 2, 2020 from https://www.liv.asn.au/LIV-Home/For-the-Community/Legal-Fact-Sheets/Powers-of-Attorney.

Manifesto Project. (n.d.). The 2008 Democratic national platform: renewing America's promise. Retrieved July 22, 2020 from https://manifestoproject.wzb.eu/.

Marshall, M. G., Jaggers, K., \& Gurr, T. R. (2016). Polity IV project: political regime characteristics and transitions, 1800-2013 - Dataset Users' Manual.

$\begin{array}{llll}\text { Retrieved } & \text { August } & 16, & 2020\end{array}$ https://www.systemicpeace.org/inscr/p4manualv2016.pdf.

Mason, J. (2011). At fundraisers, Obama says 60 percent of promises kept. Retrieved September 12, 2020 from https://www.reuters.com/article/us-usa-campaign-obamafundraising/at-fundraisers-obama-says-60-percent-of-promises-keptidUSTRE79O0IV20111025.

Monie` re, D. (1988). Le discours e lectoral. Les politiciens sont-ils fiables? Montre’al: Que’bec/ Ame'rique.

Park, A. (2009). Researchers cheer Obama's vote for stem-cell science. Retrieved September 12, 2020 from http://content.time.com/time/health/article/0,8599,1883861,00.html.

Petry, François, and Collette, Benoit. (2009). "Measuring How Political Parties Keep Their Promises.” In Do They Walk Like They Talk? Speech and Action in Policy Processes, 15:32. Studies in Public Choice. New York, USA: Springer-Verlag. 
Pe'try, F. (2002). La re'alisation des engagements du Parti que'be' cois: analyse d'ensemble. In Le Parti que'be'cois. Bilan des engagements e'lectoraux 1994-2000, ed. Pe'try, F., 161181. Que'bec: Presses de l'Universite' Laval.

Pe'try, F. and B. Collette. (2006). Le gouvernement Charest a-t-il respecte' ses promesses ? In Le Parti libe'ral. Enquête sur les re'alisations du gouvernement Charest, ed. Pe'try, F.,E' . Be'langer and L. M. Imbeau, 83- 101. Que'bec: Presses de l’Universite' Laval.

Pettit, P. (2008). Three conceptions of democratic control. Constellations, 15(1), 46-55.

Pew Research Centre. 2014. Many in emerging and developing nations disconnected from politics. $\quad$ Retrieved September $1, \quad 2020$ from http://www.pewglobal.org/2014/12/18/many-in-emerging-and-developing-nationsdisconnected-from-politics/.

Polity Fact. (n.d.). The Obameter: tracking Obama's promises. Retrieved July 26, 2020 from http://www.politifact.com/truth-ometer/promises/obameter/browse/

Pomper, G. M. (1968). Elections in America. Control and influence in democratic politics.

Toronto: Dodd, Mead \& Company.

Pomper, G. M. and S. S. Lederman. (1980). Elections in America. Control and Influence in Democratic Politics. New York: Longman.

Przeworski, A., Alvarez, M. E., Cheibub, J. A., \& Limongi, F. (2000). Democracy and development: political institutions and well-being in the world, 1950-1990. Cambridge: Cambridge University Press.

Rallings, C. (1987). The influence of election programmes: Britain and Canada 1945-79.

In Ideology, strategy, and party change: spatial analysis of post-war elections programmes in nineteen democracies, ed. Budge, I., D. Robertson and D. Hearl, Cambridge: Cambridge University Press.

Ringquist, E. J. and C. Dasse. (2004). Lies, damned lies, and campaign promises? Environmental legislation in the 105th Congress. Social Science Quarterly 85(2), 400419. 
Ritchie, D. G. (1891). Contributions to the history of the social contract theory. Political Science Quarterly, 6(4), 656-676.

Rose, R. (1984). Do parties make a difference? Chatam: Chatam House Publishers.

Royed, T. J. (1996). Testing the mandate model in Britain and in the United States: evidence from the Reagan and Thatcher eras. British Journal of Political Science 26(1), 45-80.

Royed, T. J. and S. A. Borelli. (1997). Political parties and public policy: social welfare policy from Carter to Bush. Polity 29(4), 539-563.

Royed, T. J. and S. A. Borelli. (1999). Parties and economic policy in the USA. Pledges and performance, 1976-1992. Party Politics 5(1), 115-127.

Sanderson, J. (1963). Marx and Engels on the state. Western Political Quarterly 16(4), 946955.

Semenov, Y. I. (1975). Marxism and primitive society. Philosophy of the Social Sciences, 5(2), 201-213.

Smith, Jane Silloway. (2010). Looking back to look forward: how welfare in New Zealand has

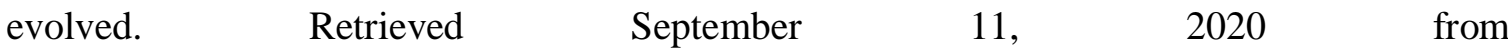
https://www.maxim.org.nz/looking_back_to_look_forward_how_welfare_in_new_zealand_h as/

Siniscalco, G. R. (2010). Developments in equal pay law: the Lilly Ledbetter Act and beyond. ABA National Conference on Equal Employment Law. Retrieved July 25, 2020 from https://www.americanbar.org/content/dam/aba/administrative/labor_law/meeti ngs/2010/2010_eeo_007.authcheckdam.pdf.

Soffen, K. (2017). After 8 years, here are the promises Obama kept — and the ones he didn't. The Washington Post, January 26. Retrieved September 13, 2020 from https://www.washingtonpost.com/graphics/politics/obama-promises/. 
Sullivan, A. (2012). Analysis: Obama's "Green Jobs" have been slow to sprout. Retrieved May, 23, 2018 from http://www.reuters.com/article/us-usa-campaign-greenidUSBRE83C08D20120413.

The American Presidency Project. (n.d.-a). Democratic Party platforms: 2008 Democratic Party $\begin{array}{lllll}\text { platform. } & \text { Retrieved } & \text { April } & 16, & 2020\end{array}$ https://www.presidency.ucsb.edu/documents/2008-democratic-party-platform.

The American Presidency Project. (n.d.-b). William J. Clinton: 42nd President of the United States: 1993 - 2001, Executive Order 13148-Greening the government through leadership in environmental management. Retrieved April 16, 2020 from https://www.presidency.ucsb.edu/documents/executive-order-13148-greening-thegovernment-through-leadership-environmental-management.

Thomson, R. (2001). The programme to policy linkage: the fulfilment of election pledges on socio-economic policy in the Netherlands, 1986-1998. European Journal of Political Research 40(2), 171-197.

Thomson, R., Royed, T., Naurin, E., Artés, J., Costello, R., Ennser-Jedenastik, L., Ferguson, M. (2017). The fulfillment of parties' election pledges: a comparative study on the impact of power sharing. American Journal of Political Science, 61(3), 527-542.

United Nations. (n.d.). Growth in United Nations membership: 1945-present. Retrieved April 25, 2020 from http://www.un.org/en/sections/member-states/growth-united-nationsmembership-1945-present/index.html.

Washington Post. (2018). Retrieved July 11, 2020 from http://www.washingtonpost.com/wpsrv/special/politics/obamas-promises/. 
Table 1. Election Promises Implementation Scale

Description $\quad$ Quantification

Full implementation 4

Above average implementation 3

Average implementation $\quad 2$

Below average implementation $\quad 1$

No implementation $\quad 0$

Below average negative implementation $\quad-1$

Average negative implementation $\quad-2$

Above average negative implementation $\quad-3$

Full negative implementation $\quad-4$ 
Table 2. State Owner Perception Index (SOPI)

(a) Example table of comparison between government tenures in a single country

\begin{tabular}{|c|c|c|c|c|}
\hline No. & Tenure & Governing party/alliance & Country & SOPI Score \\
\hline 1 & $2000-2004$ & -------------------- & $\mathrm{A}$ & 71.09 \\
\hline 2 & 2004-2008 & --------------------- & $\mathrm{A}$ & 67.50 \\
\hline 3 & 2008-2012 & --------------------- & A & 65.31 \\
\hline 4 & $1996-2000$ & --------------------- & A & 53.50 \\
\hline 5 & 1992-1996 & ---------------------' & A & 53.21 \\
\hline
\end{tabular}

(b) Example table of comparison between government tenures across countries

\begin{tabular}{lllll}
\hline No. & Tenure & Governing party/alliance & Country & SOPI Score \\
\hline 1 & $2012-2016$ & ----------------- & D & 75.81 \\
2 & $2013-2016$ & ----------------- & B & 74.60
\end{tabular}


3 2011-2016

$4 \quad 2010-2015$

5

2011-2016
C

A

E
73.92

73.21

68.67 